\title{
LEGENDA ŚLEPEGO MAKSA JAKO PODSTAWA OPRACOWANIA NOWEGO PRODUKTU TURYSTYCZNEGO ŁODZI ${ }^{1}$
}

\begin{abstract}
Abstrakt: Artykuł jest próbą zaprezentowania możliwości wykorzystania w turystyce oryginalnych wydarzeń i postaci łódzkich Bałut z okresu 20-lecia międzywojennego. Do analiz wybrano „karierę" Menachema Bornsztajna znanego w łódzkim półświatku jako Ślepy Maks. Pomimo jego ogromnej „sławy” jest on dzisiaj postacią nieznaną nawet wśród mieszkańców Starych Bałut, na których się wychował. Potwierdzają to przeprowadzone badania ankietowe wśród osób zamieszkujących tę dzielnicę. Istnieją co prawda pojedyncze wydarzenia związane z tą postacią, jednak nie tworzą one spójnego produktu turystycznego. Głównym celem artykułu jest wskazanie, w jaki sposób potencjał związany z postacią Ślepego Maksa mógłby być wykorzystany do wykreowania nowego, konkurencyjnego produktu turystycznego miasta.

Słowa kluczowe: produkt turystyczny, turystyka, turystyka literacka i filmowa, dziedzictwo kulturowe, Łódź, Bałuty, Ślepy Maks.
\end{abstract}

\section{THE LEGEND OF BLIND MAKS AS THE BASIS FOR DEVELOPING A NEW TOURIST PRODUCT OF ŁÓDŹ}

Abstract: The article is an attempt of presenting the possibilities of placing the real facts and the characters from Bałuty district in Łódź taken from Polish Interwar Period in the tourism. The "career" of Menachem Bornsztajn is taken into account in the analysis. In the region of Łódź he was known as "Slepy Maks". Despite his enormous "fame", he is an unknown character among the society of Stare Bałuty district, where he grew up. It is confirmed by survey research carried out among citizens of Stare Bałuty. The trust is that there are particular episodes related to that character, however they are not forming the coherent touristic product. The main purpose of this article is to show how the hidden potential of the story about Slepy Maks can be used to create a new, competitive touristic product of the city.

Keywords: tourist product, tourism, Łódź, Bałuty, "Slepy Maks".

\section{WSTĘP}

Postacie barwne i kontrowersyjne od zawsze budzily zainteresowanie wśród ludzi. Łódź w okresie 20-lecia międzywojennego również wykreowała taką "sławę" i wyniosła ją na piedestał jako obrońcę biednych i uciśnionych. Wokół Menachema Bornsztajna znanego jako Ślepy Maks, żyjącego w latach 1890-1960, wśród mieszkańców Starych Bałut urosła legenda, która do dziś mąci jego przeszłość, rysując go na wzór włoskiego gangstera Ala Capone. Ten początkowo drobny kieszonkowiec żydowskiego pochodzenia w błyskawicznym tempie rozwiną swoją kryminalną karierę. Przebiegły i sprytny król łódzkiego półświatka zbudował wokół siebie „imperium”. Stanął na czele żydowskiego sądu i otworzył Biuro Próśb i Podań, które stanowiło doskonałą przykrywkę dla jego przestępczego fachu.

Obecnie postacie ze świata kryminalnego, ale także policjanci i detektywi, stają się coraz bardziej popularni zarówno w literaturze, jak i przestrzeni miejskiej.
Miasta takie, jak Wrocław, Kraków czy Ystad wykorzystują ich sławę do tworzenia nowych produktów turystycznych. Łódź mając swojego Rinaldo Rinaldiniego również próbuje przywrócić go na łamy gazet, książek i scen teatralnych, niestety $\mathrm{z}$ bardzo różnym skutkiem. Pomimo to że jest to postać kontrowersyjna, jej przeszłość nie jest do końca jasna, pobudki jego działań nie zawsze były szlachetne, a czyny etyczne, to nadal stanowi nieodłączną część łódzkiej tożsamości. O Maksie śpiewano ballady, opowiadano legendy, układano wiersze. Obecnie pisze się o nim książki, wykorzystuje jego postać w filmach i spektaklach teatralnych oraz tworzy szlaki i gry miejskie. Wraz $\mathrm{z}$ zaginięciem Menachema Bornsztajna tuż przed rozpoczęciem II wojny światowej zaginęła także jego legenda, którą Łódź próbuje obecnie przywrócić.

Dotychczas powstało kilka publikacji opisujących życie i działalność Ślepego Maksa. Najbardziej kompletnym dziełem wydaje się być książka R. PIOTROW- 
SKIEGO (2014) Ślepy Maks. Historia łódzkiego Ala Capone. W swoim utworze autor czerpie z wielu źródeł próbując dociec prawdy, kim tak naprawdę był Menachem Bornsztajn oraz ile prawdy tkwi w legendach, które owiały tę postać. Bardziej kontrowersyjnym dziełem, będącym prawdopodobnie w znacznej mierze fikcją literacka, jest pozycja A. MosTOWICZA (1998) Ballada o Ślepym Maksie. Autor, próbując oddać atmosferę tamtego czasu i charakter postaci, pisze w niej m.in:

Na Bałutach w swoim domu

Kamienicznik zwykły drań

Wdowę krzywdzi, dzieci krzywdzi,

Czy nie będzie sily nań?

Czekaj ty, Kamieniczniku,

Krótka będzie władza twa,

Idzie właśnie Ślepy Maks

I ci dobrze w dupę da!...

Wdowa już w swoim mieszkaniu,

Wszyscy w koło cieszą się,

Ślepy Maks już swoje zrobił,

Jak to zrobił - każdy wie.

Kamienicznik czołga się,

Ślepy Maks mu mordę skwasił,

Oko podbil, zęby wybił.

Morał z pieśni: nie czyń zła!

Choć wiele wydarzeń $z$ ballady nie jest poparte faktami, przytoczony fragment doskonale oddaje to jak Ślepy Maks był odbierany przez mieszkańców Bałut. W okresie międzywojennym pośród zgiełku Rynku Bałuckiego w licznych bramach i na brukowanych uliczkach dało się słyszeć śpiew kataryniarzy, wychwalających czyny Menachema Bornsztajna. Pomimo drastycznych metod, jakie wykorzystywal, ludzie widzieli w nim bohatera. Jego "sława” poruszana była w wielu publikacjach, m.in. Szczurach ze złego miasta J. INDELAKA (1990) oraz publikacji A. OCHOCKIEGO (2004) Reporter przed konfesjonatem, czyli jak się w Łodzi przed wojnq robiło gazetę. Kolejnym źródłem informacji o Ślepym Maksie są także liczne artykuły o kontrowersyjnych tytułach, które pojawiały się regularnie w przedwojennej prasie. Tajemnice Bałut. Napad rabunkowy czy zemsta osobista (1931), Niesamowite przygody Ślepego Maksa. Łódzki Rinaldo-Rinaldini... (1936), Zbrodnia Ślepego Maksa herszta szajki złodziejskiej Dardanele i prezesa stowarzyszenia Dusicieli (1929), Proszę o rehabilitację i uniewinnienie (1936), Sensacje na procesie Ślepego Maksa (1935), Ślepy Maks - Anioł Pokoju (1935), Ślepy Maks - król podziemi Łodzi (1935), Zza kulis roboty Ślepego Maksa w Łodzi (1936), Skąd się wzięła przyjaźn inspektora policji $z$ hersztem bandy (1936). Są to wybrane tytuły, na które nie sposób było się nie natknąć w tamtych czasach. Życie i działalność Ślepego Maksa były pierwszorzędnym tematem na ustach mieszkańców i na łamach większości gazet. Wszystkie te źródła dają obraz prawdo- podobnego życiorysu Ślepego Maksa. Niestety zawarte $\mathrm{w}$ nich fakty nie są spójne i nie pokrywają się ze sobą.

Do dziś jego losy pozostaja zagadką. To właśnie czyni tę postać tajemniczą i ciekawą tak bardzo, że wykorzystana w umiejętny sposób, może stać się ważnym elementem turystycznego potencjału, czy nawet nowym produktem turystycznym miasta.

W przestrzeni miasta pozostało wiele kamienic, które nawiązują do życia oraz działalności Menachema Bornsztajna. Niestety, nie zachowała się restauracja Kokolobolo, która miała kluczowe znaczenie w jego kryminalnej karierze. Na cmentarzu żydowskim przy ulicy Brackiej do dziś zachował się pomnik nagrobny w miejscu, gdzie został pochowany.

Problem badawczy, jaki podjęto się rozwiązać, jest związany z identyfikacją szans na wykorzystanie legendy Ślepego Maksa do budowania nowych produktów turystycznych Łodzi. Autorzy zakładają, że pomimo wielkiej "sławy" Ślepego Maksa w okresie przedwojennym i miejsc $\mathrm{z}$ nim związanych obecnie mieszkańcy Łodzi (Starych Bałut) niewiele wiedzą na jego temat, zaś dziedzictwo $z$ nim związane nie jest widoczne $\mathrm{w}$ przestrzeni miasta, a produkty turystyczne i rekreacyjne nie są dostatecznie spopularyzowane.

Dotychczas nie zostały przeprowadzone badania weryfikujące stan wiedzy Łodzian na temat znajomości postaci przedwojennego łódzkiego półświatka ani ich opinii na temat tworzenia $w$ mieście atrakcji z nimi związanych. Poznanie kontekstu społecznego i kulturowego jest niezwykle ważne $\mathrm{w}$ tworzeniu takiego produktu. Nie poparta żadnymi badaniami próba jego wykreowania może doprowadzić do porażki rynkowej. Celem przeprowadzonych badań było poznanie postaci Ślepego Maksa, jak również sprawdzenie, czy w przestrzeni miejskiej pozostały ślady po jego życiu i działalności oraz czy są one obecnie wykorzystywane do promocji miasta. Ponadto autorzy pragnęli sprawdzić stan wiedzy mieszkańców Starych Bałut o Menachemie Bornsztajnie i zapoznać się z ich opinią na temat stworzenia fabularnej gry terenowej. Głównym celem autorów artykułu jest przedstawienie wyników przeprowadzonych badań

\section{PROBLEM BADAWCZY W ŚWIETLE LITERATURY, METODY BADAŃ I MATERIAŁY ŹRÓDŁOWE}

Poruszony problem badawczy wiąże się bezpośrednio z jednym $z$ rodzajów turystyki, jakim jest turystyka literacka i filmowa. Stanowi ona część turystyki kulturowej. Według A. STASIAKA (2009) w turystyce literac- 
kiej główny motyw podróży turystów stanowi docieranie do miejsc związanych z literaturą, na którą mogą się składać zwiedzania dawnych domów pisarzy oraz miejsc (rzeczywistych lub fikcyjnych) wspomnianych $w$ analizowanych książkach lub też miejsc związanych z bohaterami. Za turystykę filmową zaś uznaje się wszelakie podróże śladami gwiazd filmów i ich dzieł będące okazją do głębszych refleksji i osobistego przeżywania utworów. Powodem odwiedzenia danego miejsca może być zarówno książka, jak i film, stąd też można wyróżnić rodzaj turystyki zwany turystyką filmowo-literacką. M. MIKA (2008) nie wyróżnia turystyki literacko-filmowej jako oddzielnego typu turystyki. Uznaje, że stanowi ona jedynie jeden z wielu elementów kształtujących turystykę kulturową. J. KACZMAREK i in. (2010) twierdzą, że motywy związane $z$ literaturą i filmem mogą stanowić podstawę do wykreowania nowego produktu turystycznego - szlaku turystycznego. Jako przykład podają Niemiecki Szlak Baśniowy oparty na miejscach, w których toczyły się akcje baśni braci Grimm.

W badaniach posłużono się metodą ilościową, jaką była metoda sondażu diagnostycznego, oraz metodą jakościową, głównie wywiadami pogłębionymi, a także dokumentacją fotograficzną (KONARZEWSKI 2006). Zastosowane techniki badawcze ilościowe to kwerenda, czyli „osobiste poszukiwanie informacji w zasobie archiwum lub biblioteki" (SIERPOWSKI, NAWROCKI 1995), oraz ankieta będąca "metodą badań naukowych polegającą na stawianiu pytań, a następnie na opracowywaniu odpowiedzi" (PIETER 1967), zaś narzędziem badawczym był kwestionariusz ankiety definiowany jako „narzędzie zaprojektowane specjalnie do zbierania informacji, które mogą przydać się do analiz" (BABBIE 2004). Spośród technik jakościowych autorzy zastosowali wywiad niestandaryzowany swobodny, gdzie „prowadzący wywiad dysponuje tylko «ogólnym planem zagadnień», wokół których powinna skoncentrować się rozmowa $\mathrm{z}$ respondentem" (PRZYBYŁOWSKA 1978).

Ponadto przeprowadzono dokumentację fotograficzną miejsc związanych z postacią Ślepego Maksa oraz przygotowano mape tych miejsc, na podkładzie międzywojennego Planu wojewódzkiego miasta Łodzi (1937) z zaznaczonym podziałem na okręgi policyjne.

Kwerenda w Archiwum Państwowym oraz bibliotekach publicznych ukazała dużą popularność tej postaci $w$ literaturze oraz przedwojennej prasie. Natomiast wywiady $\mathrm{z}$ autorami i organizatorami gier terenowych związanych ze Ślepym Maksem (A. Sitnicką oraz Z. Szczecińskim) pozwoliły zapoznać się $\mathrm{z}$ organizowanymi przedsięwzięciami z wykorzystaniem tej postaci. Znany już jest także film dokumentalny Ten bandycki świat lat trzydziestych, w którym w rolę Ślepego Maksa wcielił się B. Wrocławski. Swój epizod Ślepy Maks miał także w filmie Hallo Szpic- bródka, czyli ostatni występ króla kasiarzy (1978), gdzie w rolę Maksa wcielił się E. Karewicz. W fazie projektu jest także szlak turystyczny po Łodzi Śladami Ślepego Maksa, płaskorzeźba króla Bałut, gra terenowa po Łodzi Śladami kariery Ślepego Maksa oraz scenariusz do filmu o Menachemie Bornsztajnie.

Badania empiryczne przeprowadzone podczas tworzenia projektu miały zróżnicowany przebieg. Uczestnicy biorący udział $\mathrm{w}$ projekcie byli zobowiązani zapoznać się z książką pt. Ślepy Maks. Historia Łódzkiego Ala Capone autorstwa R. PIOTROWSKIEGO (2014). Następnie w połowie kwietnia przeprowadzono kwerendę w Archiwum Państwowym w Łodzi oraz w Bibliotekach UŁ. Polegała ona na odnalezieniu w historycznych numerach łódzkich gazet artykułów dotyczących działalności przestępczej oraz życia Menachema Bornsztajna znanego jako Ślepy Maks.

Niebagatelne znaczenie miało spotkanie $\mathrm{z}$ aktorami przedstawienia teatralnego Kokolobolo, czyli opowieść o przypadkach Ślepego Maksa i Szai Magnata w Teatrze Nowym. Na przełomie kwietnia i maja grupa badawcza udała się do tego teatru w celu przeprowadzenia wywiadów pogłębionych z Pawłem Audykowskim (Ślepy Maks) i Bartoszem Turzyńskim (Szaja Magnat), aktorami odgrywającymi główne role we wspomnianym przedstawieniu $\mathrm{w}$ reżyserii Jacka Głomba. Celem wywiadów było poznanie motywacji, które zdecydowały o odegraniu roli oraz sposobu zdobywania wiedzy na temat bohaterów. Obydwaj aktorzy podkreślali, że przed rozpoczęciem prac nad spektaklem nie mieli żadnego pojęcia na temat Ślepego Maksa. Swoją wiedzę zaczęli kształtować dopiero $\mathrm{w}$ momencie przygotowań do roli. Odbyli liczne wycieczki po miejscach związanych z Menachemem Bornsztajnem, czy też zapoznali się ze źródłami literatury opisującymi jego karierę. Zarówno Paweł Audykowski, jak i Bartosz Turzyński podkreślali, że udział w spektaklu spowodował $\mathrm{u}$ nich zmianę poglądu na temat Łodzi. Pozwolił im poznać część historii miast oraz poczuć klimat międzywojnia. Stwierdzili też że warto, aby legenda o Ślepym Maksie była w większym stopniu popularyzowana wśród mieszkańców i turystów Łodzi. Swoje opinie oparli m.in. na podstawie żywiołowych reakcji widowni w trakcie przedstawienia. Po zakończeniu projektu wszyscy mieli okazję uczestniczyć we wspomnianym spektaklu.

Odbył się również wywiad $z$ autorem książki, od której wszystko się zaczęło, czyli z R. Piotrowskim, oraz $\mathrm{z}$ pracownikiem Wydziału Filologicznego UŁ dr Karoliną Kołodziej. Wywiad udzielony był na początku maja 2017 r. na Wydziale Nauk Geograficznych. Wysłuchane opinie oraz uzyskana wiedza na temat przedsięwzięć związanych z popularyzacją postaci Ślepego Maksa pokazała mnogość dotychczasowych działań nie tylko turystycznych związanych $\mathrm{z}$ tą postacią. 
Przeprowadzono także wywiad telefoniczny z autorami łódzkich gier terenowych dotyczących Ślepego Maksa - Aleksandrą Sitnicką oraz Zbigniewem Szczecińskim. Celem rozmowy było uzyskanie informacji na temat organizacji i ofert gier miejskich związanych z postacią Ślepego Maksa.

Na przełomie kwietnia i maja 2017 r. na bałuckich ulicach w Łodzi przeprowadzono wywiady z mieszkańcami Bałut na temat Ślepego Maksa. W ankiecie, która miała charakter anonimowy, wzięło udział 250 mieszkańców dzielnicy Bałut. Ankieta składała się z dziewięciu pytań odnoszących się do łódzkich legend oraz postaci Ślepego Maksa. W kwestionariuszu zawarto pytanie dotyczące znajomości miejsc związanych z bohaterem, jak i spektaklu pt. Kokolobolo, czyli opowieść o przypadkach Ślepego Maksa i Szai Magnata. Ostatnie pytanie dotyczyło opinii na temat zasadności stworzenia gry miejskiej opartej na historiach i przedstawicielach łódzkiego półświatka $\mathrm{z}$ okresu 20-lecia międzywojennego. Miało ono na celu określenie tego, co współcześni mieszkańcy sądzą na temat promowania w Łodzi postaci Ślepego Maksa - osoby znanej z kontrowersyjnych opinii wśród dawnych mieszkańców miasta. Na koniec umieszczona została metryczka zawierająca pytania o płeć, wiek i wykształcenie respondentów.

\section{3. ŚLEPY MAKS JAKO „BOHATER” BAŁUT W OPINII MIESZKAŃCÓW ŁODZI}

Badania dotyczące znajomości postaci Menachema Bornsztajna, zwanego Ślepym Maksem, zostały przeprowadzone przez pięcioosobową grupę studentów z I roku studiów magisterskich na kierunku ,turystyka i rekreacja" na Uniwersytecie Łódzkim w kwietniu i maju 2017 r. na obszarze Starych Bałut przy ulicach: Bazarowa, Rybna, Limanowskiego, Marysińska, Franciszkańska, Łagiewnicka, Zgierska, Wojska Polskiego, przy Bałuckim Rynku, placu Kościelnym, targowisku przy ulicy Dolnej, w Parku Staromiejskim. Metoda badawczą wykorzystywaną podczas przeprowadzanych badań był wywiad ankietowy. Miał on na celu sprawdzenie, czy mieszkańcy Starych Bałut, a także innych dzielnic Łodzi, znają postać Ślepego Maksa, a także legendy, miejsca oraz osoby $z$ nim związane. Narzędziem badawczym, jakie zastosowano był kwestionariusz ankiety. Ankieta zawierała dziewięć pytań problemowych oraz metryczkę. Sześć z dziewięciu pytań miało charakter półzamknięty, zaś trzy były zamknięte. Podczas badania przeankietowano 250 osób, które zostały przypadkowo wybrane (każda osoba z grupy przeprowadziła po 50 kwestionariuszy ankietowych) w wymienionych miejscach w rejonie Starych Bałut.
Analizując strukturę społeczno-demograficzną respondentów, którzy wzięli udział w badaniu stwierdzono, że liczba kobiet i mężczyzn była wyrównana; odpowiedzi na pytania zawarte $\mathrm{w}$ kwestionariuszu ankietowym udzieliło 126 kobiet i 124 mężczyzn. W strukturze wiekowej dominują kobiety w trzech grupach: 46-55 lat, 56-65 lat oraz powyżej 65 lat, podobnie było wśród mężczyzn, gdyż znaczący udział widoczny był w przedziałach wiekowych 46-55 oraz 56-65 lat (rys. 1).

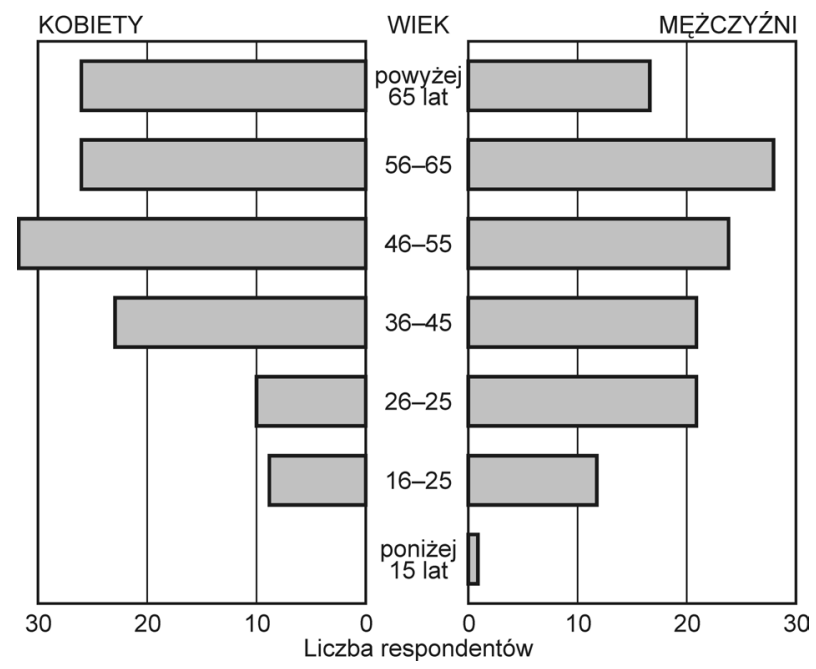

Rys. 1. Piramida wieku i płci respondentów Źródło rys. 1-9: opracowanie własne na podstawie badań terenowych

W przypadku wykształcenia zauważalna jest przewaga osób z wykształceniem średnim (aż 99 respondentów). Wykształcenie zasadnicze zawodowe zadeklarowały 53 osoby, zaś wyższe - 44. Najmniej ankietowanych miało wykształcenie policealne (29 osób) i podstawowe (25 osób).

Wśród miejsc zamieszkania respondentów dominował obszar Starych Bałut (180 osób). Jednakże odnotowano też osoby zamieszkujące inne rejony Łodzi, co ilustruje rys. 2 .

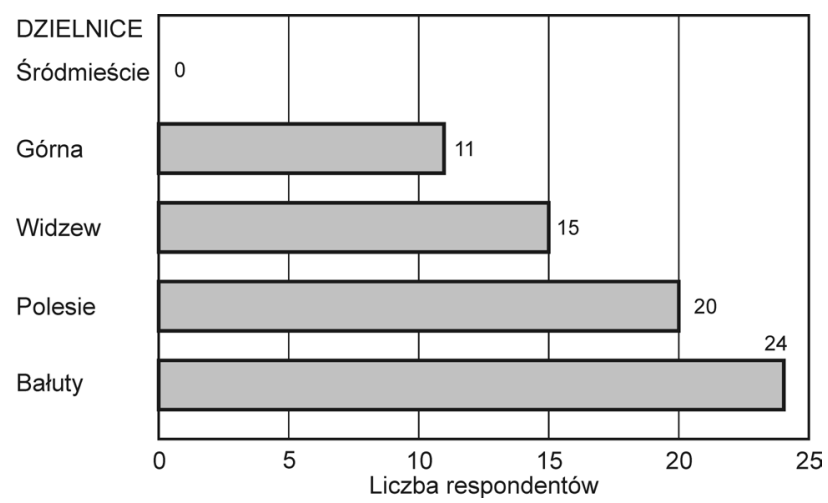

Rys. 2. Miejsce zamieszkania respondentów według dzielnic Łodzi 
Znaczący udział mają tutaj też mieszkańcy Bałut, ale rejon nowo wybudowanych osiedli znajdujących się $\mathrm{w}$ tej dzielnicy, tj. Teofilów czy Radogoszcz - 24 osoby. 20 osób zamieszkuje w dzielnicy Polesie, 15 na Widzewie, 11 w Górnej, a nie pojawiły się wśród respondentów osoby z dzielnicy Śródmieście.

W ankiecie umieszczono również pytanie zaadresowane do osób ze Starych Bałut, które miało na celu zweryfikowanie tego, od jak dawna zamieszkują ten rejon (rys. 3). Najwięcej respondentów odpowiedziało, że mieszka tam od urodzenia lub więcej niż 20 lat (26\% odpowiedzi). 18\% ankietowanych mieszka na Starych Bałutach od 5 lat, 16\% - 6-10 lat, a 14\% - 11-20 lat.

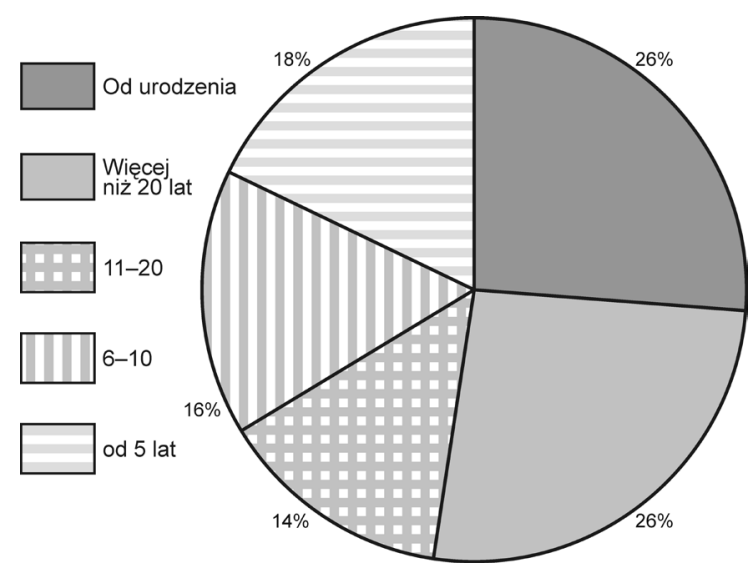

Rys. 3. Długość zamieszkiwania respondentów na Starych Bałutach w Łodzi

Respondenci byli pytani o to, czy znają jakieś legendy dotyczace Starych Bałut. Najwięcej ankietowanych, bo aż 225 osób stwierdziło, że nie zna żadnych legend, zaś 25 odpowiedziało, że znają. Wśród ankietowanych, którzy wykazali się znajomością legend dotyczących Starych Bałut najwięcej wskazań miała legenda o Ślepym Maksie (20 respondentów udzieliło takiej odpowiedzi). Pojawiały się również odpowiedzi takie, jak: legendy o Żydach (jednakże związane one były z prawdziwą historią ludności żydowskiej z czasów II wojny światowej), legenda o rybaku i łodzi oraz legenda Janusza. Pozostałe dwie legendy znane były tylko i wyłącznie z motywu, który w nich został przedstawiony, a ankietowani nie potrafili ich przytoczyć.

Odpowiedzi na pytanie dotyczące tego, kim był Menachem Bornsztajn przedstawia rys. 4. Najwięcej osób nie rozpoznawało Ślepego Maksa po jego prawdziwym imieniu i nazwisku (195 respondentów). Ankietowani, którzy kojarzyli tę postać odpowiadali, że był on Żydem (25 osób), Ślepym Maksem i gangsterem (11 osób) oraz hersztem złodziei (8 osób). Najrzadziej wskazywanymi odpowiedziami były: łodzianinem (3 osoby), a po jednej osobie udzielono odpo- wiedzi: „łódzkim Alem Capone”, „przywódcą dintojry”, „członkiem półświatka okresu międzywojennego" oraz „,bałuckim Janosikiem”.

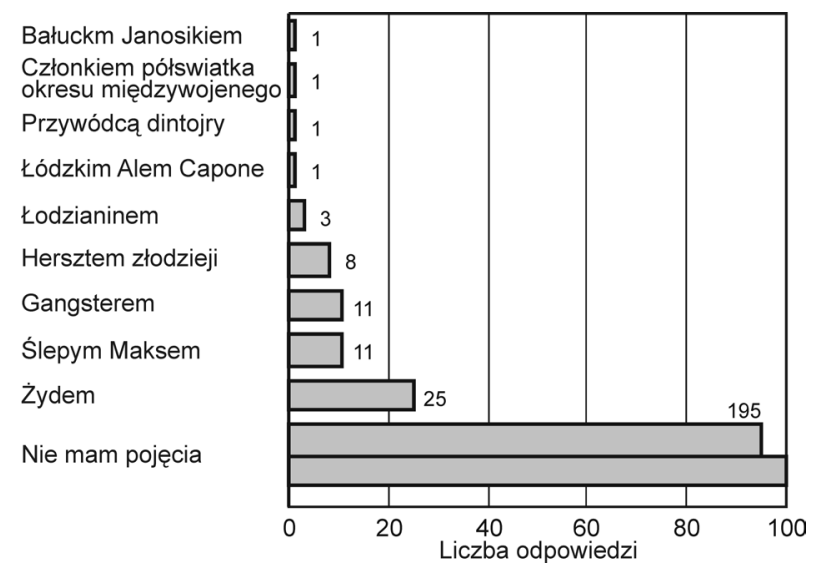

Rys. 4. Znajomość Menachema Bornsztajna przez respondentów

Kolejną kwestią, którą autorzy pragnęli zbadać było uzyskanie odpowiedzi na pytanie, kim w ogóle był człowiek zwany Ślepym Maksem. Gdy respondent zadeklarował, że słyszał o postaci Ślepego Maksa, musiał także podać, z jakiego źródła uzyskał wiedzę na jego temat. Spośród 250 ankietowanych aż 75\% (188 osób) stwierdziło, że absolutnie nie ma pojęcia, kim był Ślepy Maks. Pozostałe 62 osoby potwierdziły znajomość postaci. Wśród deklarowanych źródeł w znaczącej większości pojawiły się takie, jak: prasa, opowieści rodziców oraz Internet (rys. 5).

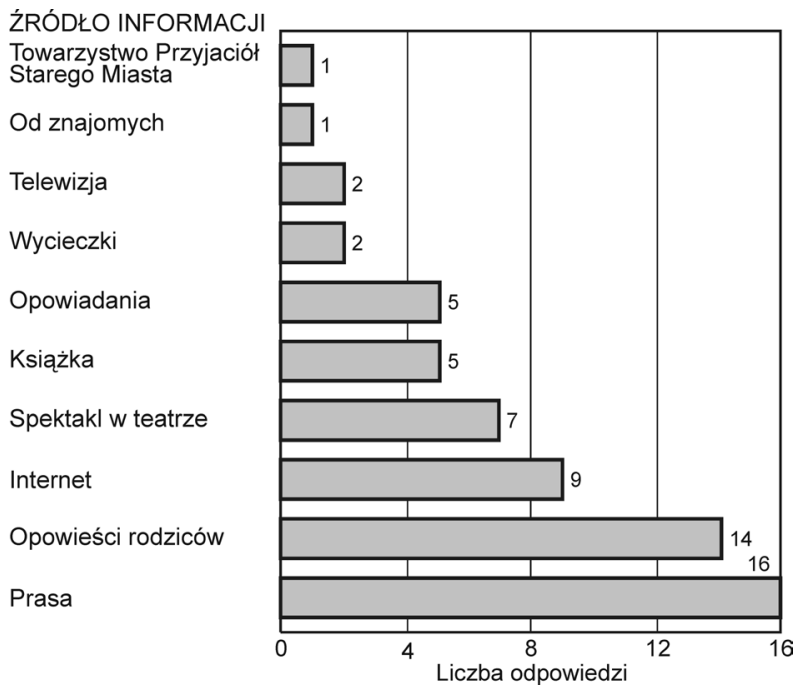

Rys. 5. Źródła wiedzy respondentów na temat postaci Ślepego Maksa z Łodzi

Następny problem dotyczył znajomości innych postaci związanych bezpośrednio z legendą Ślepego Maksa. Odpowiedzi na to pytania udzieliło 162 respondentów. $86 \%$ badanych nie potrafiło przytoczyć 
żadnej z postaci. Reszta ankietowanych wśród postaci wymieniła jedynie: Baldermana, Szaję Magnata, komisarza Noska, jak również Arona Goldberga. Najbardziej znaną postacią jednak okazał się Balderman, zaś najmniej Aron Goldberg (rys. 6).

W następnym pytaniu autorzy postanowili dowiedzieć się, jakie respondenci znają miejsca związane ze Ślepym Maksem i czy w ogóle słyszeli o takich miejscach. Spośród 162 ankietowanych jedynie 19\% zadeklarowało, że zna takie miejsca.

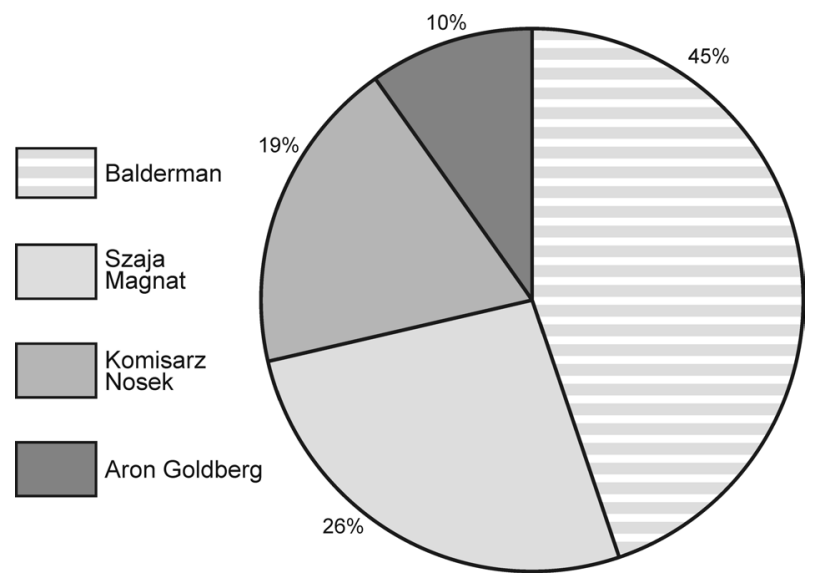

Rys. 6. Znajomość postaci związanych z legendą o Ślepym Maksie w Łodzi

Najczęściej wymienianymi miejscami były restauracja "Kokolobolo" będąca prawdopodobnie obiektem, w którym Ślepy Maks spotykał się ze swoją szajką oraz plac Wolności, gdzie według różnych źródeł dokonał morderstwa na Baldermanie. Respondenci wskazali również: ulicę Piotrkowską, ulicę Pomorską oraz okolice Grand Hotelu (rys. 7).

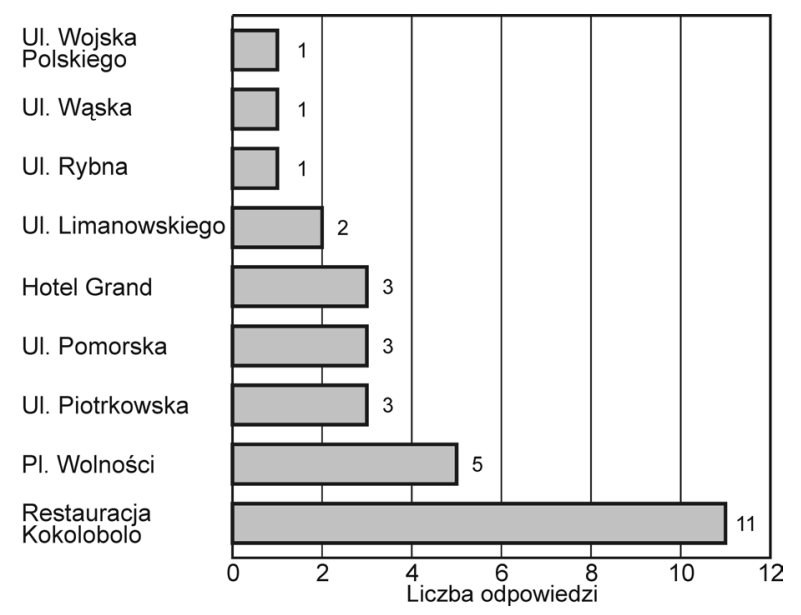

Rys. 7. Miejsca związane ze Ślepym Maksem w Łodzi

Kolejne pytanie dotyczyło uczestnictwa respondentów w spektaklu teatralnym Kokolobolo, czyli opowieść o przypadkach Ślepego Maksa i Szai Magnata wysta- wianym na deskach łódzkiego Teatru Nowego im. Kazimierza Dejmka. W ten sposób autorzy pragnęli sprawdzić, czy uczestnictwo w tym spektaklu ma jakiekolwiek przełożenie na znajomość historii Ślepego Maksa. Pytanie to zostało skierowane do wszystkich ankietowanych. Spośród 250 osób w przedstawieniu uczestniczyło jedynie 11 osób (4\%) i miały one dość dużą wiedzę oraz znajomość tematu Ślepego Maksa.

Autorzy pragnęli poznać także opinię respondentów na temat stworzenia gry miejskiej opartej na postaciach łódzkiego półświatka okresu 20-lecia międzywojennego (rys. 8). Prawie połowa z 250 ankietowanych oceniła, że jest to co najmniej dobry pomysł. Znaczna część ankietowanych nie potrafiła jednoznacznie podać swojej opinii na ten temat. Wynikało to $\mathrm{z}$ tego, że osoby te nie wiedziały nic na temat Ślepego Maksa.

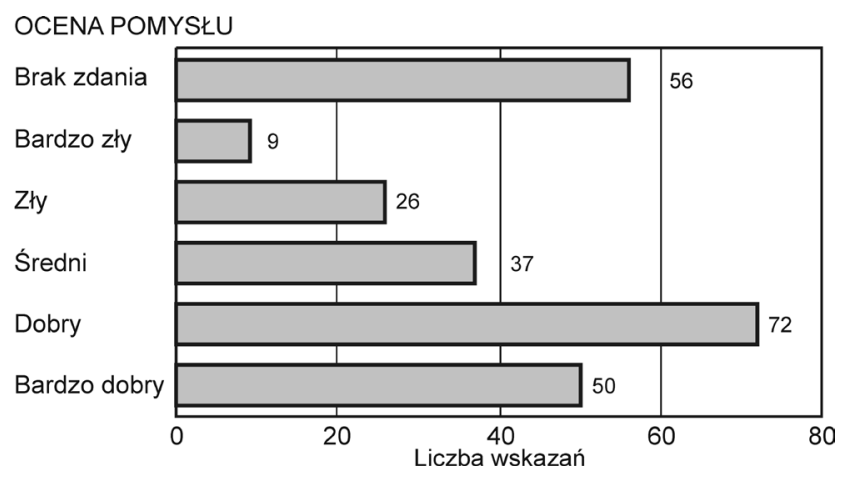

Rys. 8. Opinie respondentów dotyczące stworzenia gry terenowej opartej na postaciach łódzkiego półświatka okresu 20-lecia międzywojennego

Wszystkie powyższe statystyki i odpowiedzi udzielone przez respondentów $\mathrm{w}$ pełni potwierdzają sformułowaną przez autorów tezę. Rzeczywiście mieszkańcy Łodzi w znikomym stopniu znają postać Ślepego Maksa oraz legendy i historie $z$ nim związane. $\mathrm{Na}$ stan ten nie miało wpływu aktualne miejsce zamieszkania respondentów. Bez względu na to, czy ktoś był mieszkańcem Bałut, czy też innych łódzkich dzielnic w takim samym stopniu znał Ślepego Maksa. Wpływu na to nie miała również długość okresu zamieszkiwania na Starych Bałutach. Na znajomość postaci znaczącego wpływu nie miał też wiek respondentów. Jedynym znaczącym czynnikiem wpływającym na poziom wiedzy ankietowanych był udział w spektaklu teatralnym. Małą znajomość tematu wśród ankietowanych potwierdza zdecydowana dominacja odpowiedzi negatywnych odnośnie do pytania o ślepego Maksa lub też brak jednoznacznych opinii na jego temat. Pewnej zależności można również dopatrywać się w ocenie pomysłu utworzenia gry miejskiej opartej na postaciach łódzkiego półświatka z okresu 20-lecia międzywojennego. Brak wiedzy na 
temat Ślepego Maksa oznaczał automatycznie brak zdania na temat pomysłu. Wielu ankietowanych czuło jednak, że jest to co najmniej dobry pomysł.

Zdaniem autorów, przedsięwzięcia związane z propagowaniem i popularyzowaniem postaci Ślepego Maksa i legend z nim związanych jest dużą szansą na wykreowanie nowego wizerunku Łodzi. W tej chwili wizerunek ten jest raczej negatywny. Łódź kojarzona jest jako miasto poprzemysłowe, zaniedbane, ze znikomym potencjałem turystycznym. Wykorzystanie motywu związanego ze Ślepym Maksem pozwoliłby $\mathrm{w}$ pewnym stopniu poprawić ten wizerunek, jak i zwiększyć ofertę turystyczną miasta.

\section{PODSUMOWANIE}

Problemem badawczym było próba określenia możliwości wykorzystania postaci Menachema Bornsztajna zwanego Ślepym Maksem do przygotowania nowego oryginalnego produktu turystycznego Łodzi.

Przeprowadzone przez autorów badania oraz ich wyniki w pełni udowodniły, że postać Ślepego Maksa jest słabo zakorzeniona w świadomości współczesnych mieszkańców Łodzi, nawet Starych Bałut. W szczególności pokazały to odpowiedzi udzielone przez respondentów na pytania zamieszczone w kwestionariuszu ankietowym. Znikoma liczba osób wykazała znajomość jakichkolwiek aspektów związanych z życiem i karierą Menachema Bornsztajna. Wiedza, jaką wykazali się respondenci na temat $z$ miejsc związanych ze Ślepym Maksem jest także niewielka. Respondenci uznali, że najbardziej związany był Ślepy Maks z restauracją Kokolobolo, placem Wolności, ulicą Piotrkowską i ulicą Pomorską oraz z Grand Hotelem.

Znajomość biografii Ślepego Maksa przez osoby biorące udział w ankiecie jest bardzo ograniczona. Wykazano, że najważniejszymi postaciami związanymi ze Ślepym Maksem był: Balderman, Szaja Magnat, komisarz Nosek i Aron Goldberg. Jednak wśród najbardziej znanych legend bałuckich wymieniano tę o Ślepym Maksie, o Żydach, o rybaku i łodzi oraz legendę o Januszu.

Źródłem informacji o Ślepym Maksie była przede wszystkim prasa, opowieści rodziców, informacje pozyskane z Internetu, spektakl teatralny Kokolobolo, czyli opowieść o przypadkach Ślepego Maksa i Szai Magnata. Nieliczne osoby informacje o Ślepym Maksie uzyskały z literatury, wycieczek, telewizji, od znajomych oraz w Towarzystwie Przyjaciół Starego Rynku.

Nieodgadniona postać Ślepego Maksa została bohaterem sztuki teatralnej, ballady i gier miejskich.
Respondenci (ponad połowa) w ankietach wykazali, że gra miejska związana z postacią Ślepego Maksa to dobry pomysł.

Analiza przeprowadzonego badania ankietowanego wykazała, że współcześni mieszkańcy Łodzi uznali postać Ślepego Maksa za raczej nieznaną w historii Łodzi. Pomimo wielkiej kryminalnej "sławy" Ślepego Maksa w okresie przedwojennym i miejsc z nim związanych obecnie mieszkańcy Łodzi, w tym Starych Bałut, niewiele wiedzą na jego temat, zaś dziedzictwo z nim związane nie jest widoczne w przestrzeni miasta, a produkty turystyczne i rekreacyjne nie są dostatecznie spopularyzowane.

Ze względu na niewielką znajomość przez współczesnych mieszkańców Łodzi biografii Menachema Bornsztajna, zwanego Ślepym Maksem, należałoby przybliżyć jego historię życia i działalności, szczególnie jako łódzkiego Janosika. Organizacja czasowej wystawy, np. na Starym Rynku w Łodzi, przypomniałaby postać Ślepego Maksa. Na kanwie historii „bohaterów” łódzkiego półświatka okresu międzywojennego ukazanie jego tajemnic, w tym tajemnic Ślepego Maksa, mogłoby być przyczynkiem do powstania serialu bądź filmu o losach i działalności miejskiej legendy. Dodatkowym powodem zaznajomienia się z historią Ślepego Maksa mogłoby być utworzenie tzw. escaperoomów w rejonie Starego Miasta i Rynku Bałuckiego, których tematyka nawiązywałaby do jego kariery, publikacja komiksów i cyklicznych wydawnictw, których tematyką byłaby kryminalna działalność Menachema Bornsztajna, gra miejska pt. Kokolobolo, przywrócenie restauracji na wzór dawnej knajpy Kokolobolo, stworzenie pamiątek dotyczących osoby Ślepego Maksa (np. kubki, breloczki, torby).

Zdając sobie sprawę z pewnych wątpliwości związanych $\mathrm{z}$ etyczną stroną proponowanych przedsięwzięć należałoby wykorzystać doświadczenia, jakie mają inne, nie tylko polskie, ale także światowe centra turystyczne w tym zakresie, które mając podobny potencjał przyciągają rokrocznie tysiące turystów.

\section{PRZYPIS}

${ }^{1}$ Artykuł jest podsumowaniem projektu badawczego realizowanego przez studentów I roku studiów magisterskich na kierunku "turystyka i rekreacja” w ramach przedmiotu „Projekt PBL" pod opieką naukową dr. hab. prof. UŁ Bogdana Włodarczyka.

\section{BIBLIOGRAFIA}

BABBIE E., 2004, Badania społeczne w praktyce, Wydawnictwo Naukowe PWN, Warszawa.

INDELAK J., 1990, Szczury ze złego miasta, Wydawnictwo Łódzkie, Łódź. 
KACZMAREK J., STASIAK A., WŁODARCZYK B., 2010, Produkt turystyczny Pomyst Organizacja, Zarzadzanie, Polskie Wydawnictwo Ekonomiczne, Warszawa, s. 142-151.

KONARZEWSKI K., 2000, Jak uprawiać badania oświatowe Metodologia praktyczna, Wyd. Szkolne i Pedagogiczne Spółka Akcyjna, Warszawa.

MostowiCZ A., 1998, Ballada o Ślepym Maksie, Wyd. Biblioteka „Tygla Kultury”, Łódź.

MIKA M., 2008, Formy turystyki poznawczej [w:] red. W. KUREK, Turystyka, Wydawnictwo Naukowe PWN, Warszawa, s. $210-214$

Niesamowite przygody „Ślepego Maksa”. Łódzki Rinaldo-Rinaldini (...), 1946, „Express Ilustrowany", 13.05.1946 r.

OCHOCKI A., 2004, Reporter przed konfesjonatem, czyli jak się w Łodzi przed wojna robiło gazetę, Wyd. Literatura, Łódź, s. 66-75.

PIETER J., 1967, Ogólna metodologia pracy naukowej, Ossolineum, Wrocław.

PIOTROWSKI R., 2014, Ślepy Maks Historia Łódzkiego Ala Capone, Polskie Wydawnictwo Naukowe, Warszawa.

Plan wojewódzkiego miasta Łodzi, 1937, Wydział Budownictwa Zarządu Miejskiego, Łódź.

Prosze o rehabilitacje i uniewinnienie, 1936, „Głos Poranny”, 15.10. $1936 \mathrm{r}$.
PRZYBYŁOWSKA I., 1978, Wywiad swobodny ze standaryzowana lista poszukiwanych informacji i możliwości jego zastosowania w badaniach socjologicznych, "Przegląd Socjologiczny", 30, s. 63-66.

SIERPOWSKI S., NAWROCKI S., 1995, Metodyka pracy archiwalnej, UAM, Poznań, s. 249-253.

Sensacje na procesie Ślepego Maksa, 1935, „Głos Poranny”, 9.05. $1935 \mathrm{r}$.

Skąd się wzięła przyjaźn inspektora policji z hersztem bandy, 1936 "Orędownik", 16.10.1936 r.

STASIAK A., 2009, Turystyka literacka i filmowa, [w:] K. Buczkowska, A. Mikos von Rohrscheidt (red.), Wspótczesne formy turystyki kulturowej, t. 1, Akademia Wychowania Fizycznego im. E. Piaseckiego w Poznaniu, Poznań.

Ślepy Maks - Anioł Pokoju, 1935, "Głos Poranny”, 11.05.1935 r.

Ślepy Maks - król podziemi Łodzi, 1935, „Głos Poranny”, 7.05. 1935 r.

Tajemnice Batut. Napad rabunkowy czy zemsta osobista, 1931, „Dziennik Łódzki”, 10.12.1931 r.

Zbrodnia "Ślepego Maksa" herszta szajki złodziejskiej "Dardanele" $i$ „prezesa” stowarzyszenia „Dusicieli” (...), 1929, „Express Wieczorny Ilustrowany", 20.09.1929 r.

Zza kulis roboty "Ślepego Maksa" w Łodzi, 1936, "Orędownik”, 15.10.1936 r. 